\title{
RESEARCH ON SNOW COVER IN CHINA AND THE AVALANGHE PHENOMENA OF BATURA GLAGIER IN PAKISTAN
}

\author{
By ShI YAfeng* and Wang Wenying $†$ \\ (Lanzhou Institute of Glaciology and Cryopedology, Academia Sinica, Lanchou (Lanzhou), \\ Peoples Republic of China)
}

\begin{abstract}
This paper summarizes the state of research in China on snow cover, snow-drift control, and avalanche defences, and also reports the results of observations of avalanching above Batura Glacier, Pakistan, during two expeditions.

Résuaś. Recherches sur $l e$ manteau neigeux en Chine et sur les phénomênes d'evalonche dans be Batura Glacier au Pokistan. Ce rapport résume l'état des recherches en Chine sur le manteau neigeux, le contrôle du chasseneige et les défenses contre l'avalanche ; il donne aussi les résctlats d'observations sur l'activité des avalanches au-dessus du Batura Glacier au Pakistan, au cours de deux expéditions.

Zusammenfassunc. Untersuchangen aber die Schneedecke in China und das Lawinenphänomen am Batura Glacier in Pakistan. Die Arbeit berichtet zusammenfassend über den Stand der Forschung über die Schneedecke, die Schneedrift und den Lawinenschutz in China; sie enthăle ausserdem das Ergebnis von Beobachtungen der Lawinentảtigkeit am Batura Glacier in Pakistan während zweier Expeditionen.
\end{abstract}

\section{RESEARCH ON SNOW COVER IN CHINA}

China is one of the countries where snow cover is extensively distributed at middle and low latitudes. The snow cover in China belong to two categories, permanent snow cover and seasonal snow cover. The former is distributed above snow line in the regions of high mountain and plateau in west China. It coincides with the glacier region. The latter is generally distributed in the vast regions north of lat. $25^{\circ} \mathrm{N}$. North-east China and northern part of Sinkiang Uighur Tzu-chih-ch'ü (Xinjiang Uygur Zizhiqu) are the seasonal snow cover regions of maximum thickness.

We put stress on the following three subjects in our researches on snow cover in China.

\section{Snow-cover geography and its significance in the productivity of agriculture and livestock breeding}

In recent years we have made comparatively extensive researches on the time and space distribution of snow cover in China, regional properties, climatic division of snow cover and its significance in the productivity of agriculture and livestock breeding. We have realized that snow cover is an important water resource and plays a role of preserving heat and moisture in the top soil in winter. It is of great significance in the nourishment of river flows.

\section{Anti-avalanche and snow-drift research}

Snow-drift and avalanche damage caused by seasonal snow cover often occurs in winter and spring in north-east and north-west China and on Ch'ing-hai Tibetan Plateau (Qinghai Xizang Gaoyuan). They cause serious disruption of communication and transportation, the construction of factories and mines, and the production of agriculture and livestock breeding. Since 1967 , Lanchou Institute of Glaciology and Cryopedology, Academia Sinica, and other state organs have organized avalanche and snow-drift protection in T'ien-shan. Since then we have conducted experimental research on snow in motion - snow-drifts and avalanches. According to our observations, stationary measurements, and experiments with wind-tunnel simulation tests of snow-drifts, we have got to know part of the systematic formation and 
development of snow-drifts. In the course of our field work for protection from snow-drift, we have found out some effective methods of protection. In addition, we have surveyed, though still at an initial stage, the distribution and occurrence of avalanches in T'ien-shan. By making engineering experiments we have offered proposals for preventing avalanches. Effects have been shown to a certain extent.

\section{Research on physical and mechanical properties of snow cover}

At present, in our programme for the prevention of avalanches, our researches on physical and mechanical properties of snow cover are mainly concentrated on the density of snow, snow-crystal change, the temperature of snow cover, the metamorphism of snow, the friction properties of snow, and the determination of the mechanical properties of snow cover, such as its hardness, compressive strength, tensile strength, shear strength, fracture strength, and so on. All these have to a certain extent filled the blanks in the research on snow cover in Ghina. But we have not yet carried on our researches to the thermal, electrical, acoustical, and optical properties of snow.

\section{The avalanche phenomena of Batura Glacier in Pakistan}

The Karakoram Highway, built jointly by China and Pakistan, crosses the Batura Glacier terminus on the right bank of the Hunza River. The 1973 flood damaged the highway and the bridge over the Batura channel. In order to propose a reasonable reconstruction project, the government of the Islamic Republic of Pakistan and the People's Republic of China agreed that a research group of Chinese scientists be sent to Batura Glacier. The group made investigations in the Batura Glacier region from April 1974 to November 1975, and May to December 1978. During the expedition, we found some very interesting phenomena on the avalanches and ogives of the glacier.

Batura Glacier, with a length of $59.2 \mathrm{~km}$, has a total area of $285 \mathrm{~km}^{2}$. The snow line in the drainage basin ranges from 4700 to $5300 \mathrm{~m}$ a.s.l. The accumulation area above the snow line reaches a total of $144 \mathrm{~km}^{2}$. The snow-fall is abundant. By measuring the ice thickness of the annual layers in the firn basin and the annual discharge of the melt water of the glacier, we roughly estimated that annual precipitation above the snow line may be over $2000 \mathrm{~mm}$. Owing to such abundant precipitation, together with high and steep slopes of the Hunza Karakoram on the southern side of Batura Glacier, avalanches occur frequently, and become the main source of nourishment of the glacier. As Visser writes (Visser and VisserHooft, 1938):

"Nowhere else have I heard such uninterrupted avalanches thunder as in this part of the
Karakoram. This incessant roar provides the solution of the problem of how this long
valley with its small née fields gets its fodder. We saw a further solution in the enormous
blocks of ice and snow lying heaped up on the glacier, and also the indented tracks of dust
avalanches which were everywhere visible on the ice-armoured walls."

When we came to Camp VI which was established on the glacier at $4500 \mathrm{~m}$ a.s.l. at 11 p.m. on the night of 9 August 1974, a large avalanche from Hunza Karakoram occurred. The thunderous noise came suddenly. The door-screens of the tents were opened by the air pressure wave of the avalanche. The powerful dust cloud followed for twelve minutes successively. The vertical displacement of this avalanche was about $2500 \mathrm{~m}$. The magnitude of the avalanche deposits was estimated at $30000 \mathrm{~m}^{3}$.

The avalanches of Batura Muztagh are quite representative. They are of frequent occurrence. 
Our Camp III was established on the edge of Batura Glacier opposite the Muztagh, the highest peak of Hunza Karakoram (7 $795 \mathrm{~m}$ a.s.1.). It provided the best opportunity for studying the avalanches of the Muztagh. Mr Bai Zhongyuan,* a member of our group, carried out eight days of observations. In addition we made investigations from helicopter and adventurously reached the lower parts of the avalanche path for surveying and studying. The brief results are as follows:

\section{t. Distribution and probability of the avalanches of the Batura Muztagh}

The source of avalanches is distributed on the ridges stretching south-east and north-west from the Muztagh peak. These ridges are in serrated form. Most slopes are very steep but that from the peak down the Batura first ice fall is relatively moderate. Snow attaches to the tidges and precipitous slopes, and once it is out of balance, avalanches would occur and nourish the glacier. It is a basic material condition of glacier. As the avalanche nourishment is unequal from year to year, the velocity of the glacier movenent and the width of the ogives are also unequal. Because of topographic difficulties the avalanche region is inaccessible. Mr Bai merely took observations from a far distance and got the data in Table I. Table I shows examples of some avalanches of the Batura Muztagh. The avalanches, which were clearly viewed from 3 to $4 \mathrm{~km}$ away, were comparatively large, and such large avalanches were found to happen four times a day. As to the time of occurrence, they were generally in the afternoon, and more often happened when the weather suddenly turned fine right after a snow fall.

Table I. Statistical, table of the avalanghes of the Batura Muztagh piri basin

Date

at June 1974

22: June 1974

24. Jime 1974

25. June 1974

26 June $: 974$

1) June 1974

29. June 1974

IJuly 1974 snow cloud snow cloud

\section{Description}

Comparatively large avalanche with

Avalanche fell like a cascade

Comparatively large avalanche with

Large avalanche with snow cloud

Large avalanche with snow cloud

Avalance fell like a cascade

Avalance fell like a cascade

Avalance fell like a cascade

Occurrence
time
$\mathrm{h}$

10.50 to $16.20 \quad 6$

10.20 to 12.002

10.25 to 57.00

21.40 to 22.18

08.42 to 18.00

10.05 to 15.00

09.45 to 20.28

10.20 to 12.10
7

2

6

5

4

2

\section{The damage from the avalanches of the Batura Muztagh}

In 1959, Dr Keith Warburton, the leader of the Batura Muztagh Expedition whose main objects were a mountaineering reconnaissance of the Batura Muztagh, and his four companions unfortunately lost their lives while climbing.

Dr Warburton set out with four of the party, two Englishmen and two Germans, on 23 June to climb the Batura Muztagh. On about 28 June a Pasu native hunter on the Fatimahal had watched with his binoculars as two figures climbed steadily on a shoulder which lies about $450 \mathrm{~m}$ below the summit at $7795 \mathrm{~m}$ a.s.l. From 2 to 5 July it rained and snowed heavily at Hase Camp. So much precipitation happened only once in $5^{\circ}$ years. It was speculated that Dr Warburton's expedition was then probably working on the highest peak of the Batura

- Wade-Giles: Pai Chung-yuan. 
Muztagh summit, and later, though search parties were sent out, no trace of the five m their camp was found. It must be assumed that Dr Warburton with his four companior buried by snow and avalanches.

In July 1975, the Batura Glacier Investigation Group of China found remains Warburton's expedition at a place $3500 \mathrm{~m}$ a.s.l., such as a climbing shoe, a book, a har some nails for tents, etc. In July $197^{8}$ more remains were found, again on the glac $34^{80} \mathrm{~m}$ a.s.l. This time a hat, a climbing shoe, clothes, glasses, a camera, an exposure 1 purses, matches, and many cans were found. As for glasses, hat, camera and underwear were carried by their owners on the summit. From this evidence, it is believed that th men of Dr Warburton's expedition met their death here and were buried by the aval:

\section{Estimation of avalanche transportation process from the Warbutton remains}

Dr Warburton's remains supply information for estimating the transportational pro avalanches.

We supposed that Dr Warburton with his four companions died at a place about 7 a.s.l. Judging from the fact that there is no steep slope in this section, that during our there no large avalanche occurred, and that the book and some other remains were $k$ good order, we assumed that probably the distance of movement and the difference of of that avalanche is small.

The remains of Dr Warburton were first found in 1975 , on the ninth ogive at $3500 \mathrm{~m}$ the other remains were found later in 1978 , on the twelfth ogive at $34^{80} \mathrm{~m}$ a.s.l. By con tion, comparison, and repeated photographing it is proved that one ogive is formed in (Figs I to 5 ).

From Figure I we know that ogives were pushed by new formations, the width : between two successive ogives along the axis. But there is no definite ratio among them width of ogives may represent to a certain degree the yearly accumulation of snow.

From Figure I we suggest, that in the year 1959, snow-fall was abundant in I Muztagh and avalanches occurred more frequently than in 1974. From a Sabina sample at a place $3800 \mathrm{~m}$ a.s.l, on Batura Glacier, its ring for the year 1959 is compar: narrower than those in the year before and after. J. I. Edwards ( 1960 ) reported tha

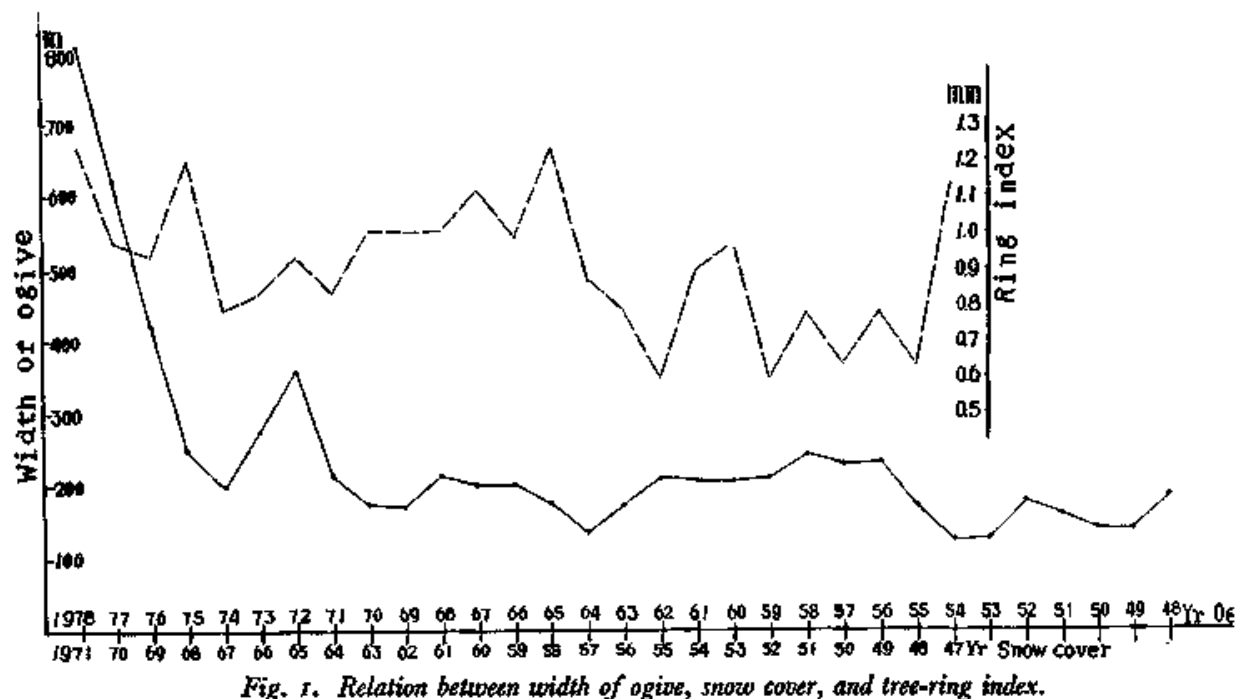




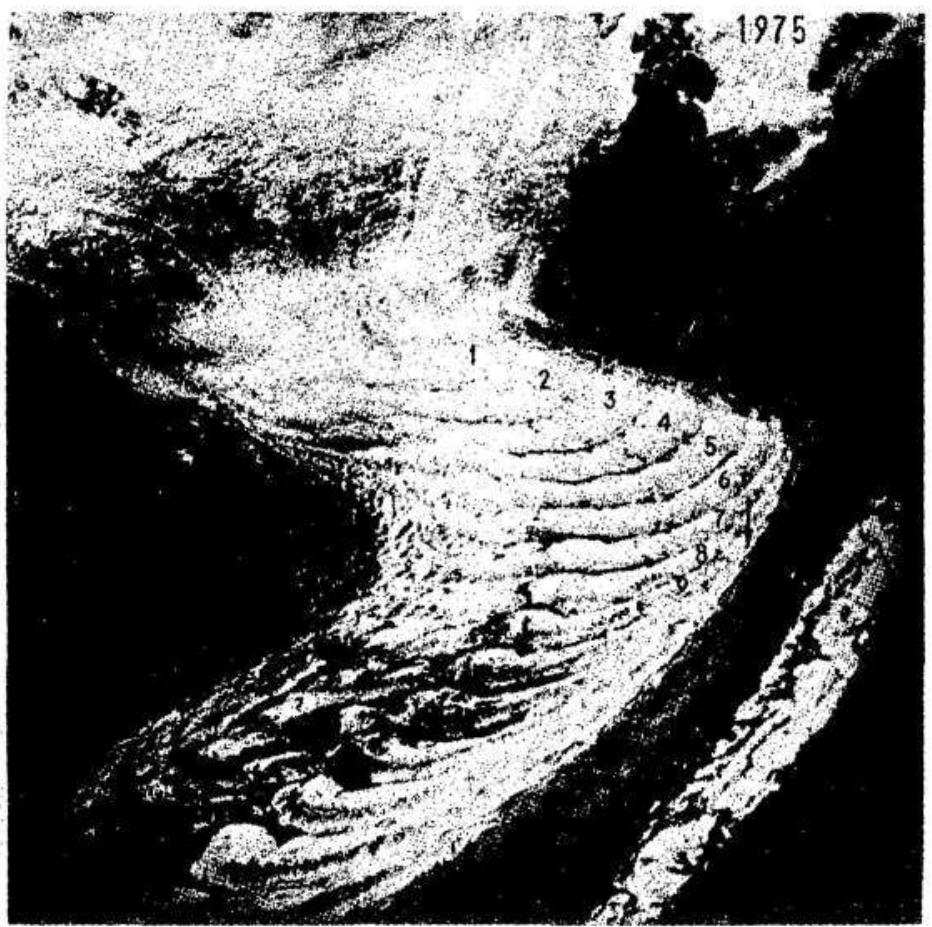

Fig. 2. The ogives of Batura Glacier, photograph from helicopter, 31 August 1975.

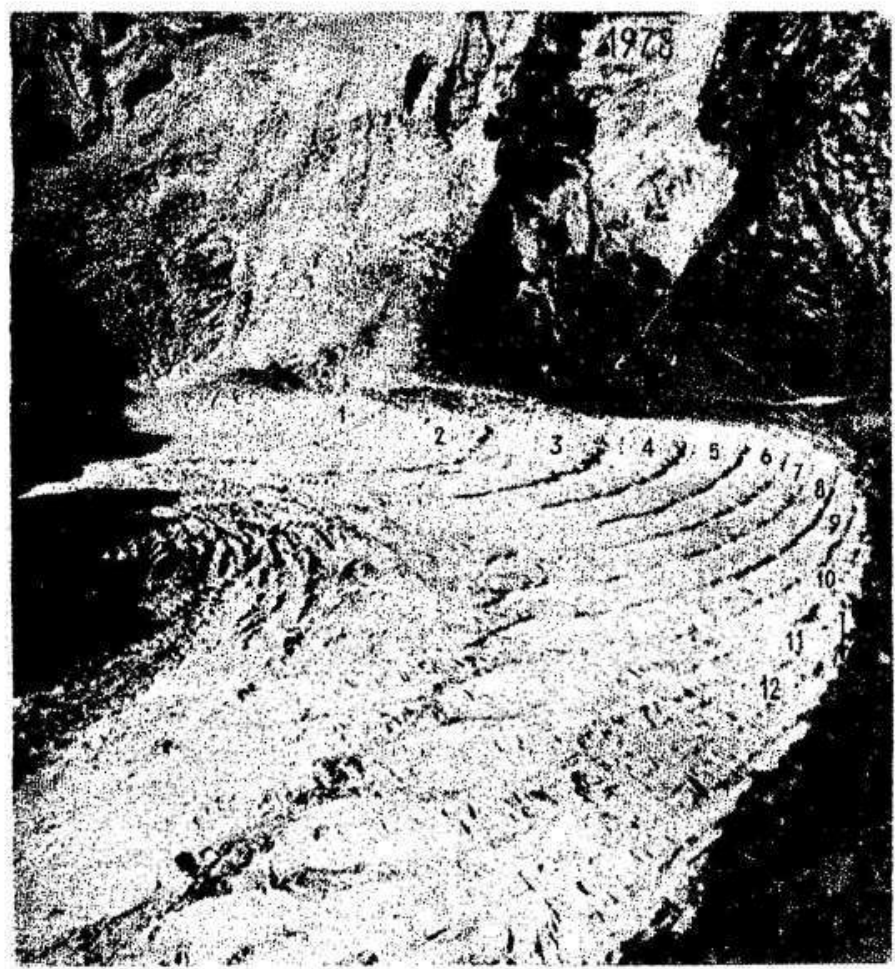

Fig. 3. The ogives of Batura Glacier, photograph from helicopter, 1 November 1978. 


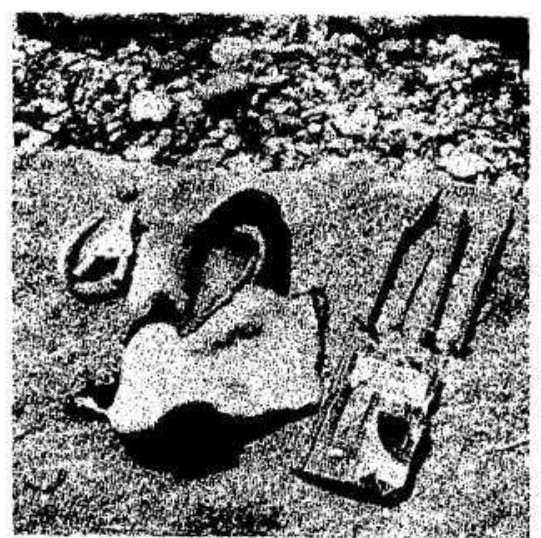

Fig. 4. The remains of Dr Warburton found in 1975.

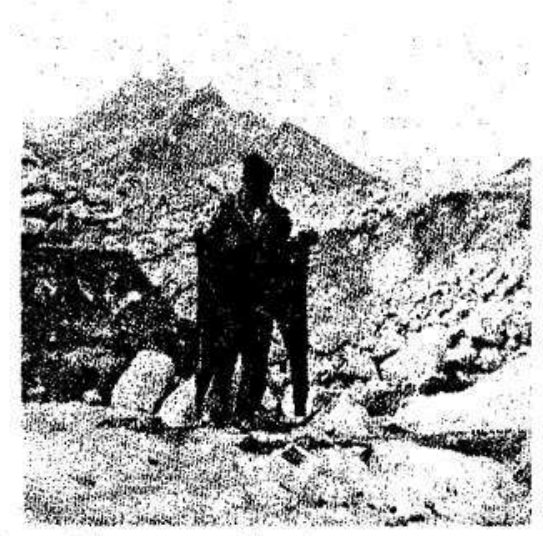

Fig. 5. The remains of Dr Warburion found in 1978.

the end of June to early July, when Dr Warburton was climbing the summit, avalanches occurred five or six times every day. This can be compared with 1974 in which the daily occurrence of avalanches was only four times a day. Thus from the variation of the width of ogives we have some information on the yearly changes of snow-fall in the past.

The horizontal distance from the place at about $7000 \mathrm{~m}$ a.s.l. below the Batura Muztagh summit to the last ogive is about $7 \mathrm{~km}$. The time required to transport the snow and ice from the place of their death to the foot of the Batura Muztagh can be estimated from Dr Warburton's remains. They died in 1959 and up to 1978 nineteen years had elapsed. Their remains were found on the twelfth ogive. This means that it took about seven years for the remains to cover a horizontal distance of $7000 \mathrm{~m}$, i.e. about $1000 \mathrm{~m} /$ year. In summer 1978 , at the survey point that lies in the middle reach between the summit and the last ogive, we found the velocity of the glacier to be $1245.3 \mathrm{~m} /$ year. The motion velocity in the ice fall measured by J. I. Edwards was about I $300 \mathrm{~m} /$ year. These two values are very close. It is generally accepted that the breaking of ice to the surface represents the change in velocity. The velocity in the ice-fall area is faster than the mean velocity from Muztagh summit to the last ogive by about $30 \%$.

Avalanches occur frequently on the south-east slope of the Batura Muztagh, their maximum vertical displacement reaches about 3000 to $3500 \mathrm{~m}$, and the lowest topographical snow line lies at $4000 \mathrm{~m}$ a.s.l. in this region.

\section{REFERENGES}

Edwards, J. 1. 1960. The Batura Muztagh Expedition, 1959. Alpine Journal, Vol. 65, No. 300, p. 48-52.

Finsterwalder, R. rg6o. German glaciological and geological expeditions to the Batura Mustagh and Rakaposhi Range. Journal of Glaciology, Vol. 3, No. 28, p. 787-88.

Shih Ya-feng and others, ed. 1980. K'a-la-k'un-lun-shan Pa-t'o-la ping-ch'uan k'ao-ch'a yü yen-chiu [Professional papers on the Batura Glacier, Karakoram Mountains]. [Edited by Shih Ya-feng, Chang Hsiang-sung, and Pai Chung-yuan.] Peking, K'e-hsüeh Ch'u-pan-she.

Visser, P. C., and Visser-Hooft, J., ed. 1938. Wissenschaftliche Ergebnisse der Niederländischen Expeditionen in den Karakorum und die angrenzenden Gebiete in den fahren 1922, 1925, 1929/30, und 1935. Bd. 2. Glaziologie. Leiden, E. J. Brill. 